\title{
Effects of Phosphate, Glucose, and Ammonium on Cell Growth and Lincomycin Production by Streptomyces lincolnensis in Chemically Defined Media
}

\author{
M. D. Young* and L. L. Kempe \\ Department of Chemical Engineering, University of Michigan, \\ Ann Arbor, MI 48109 \\ F. G. Badert \\ Fermentation R\&D, The Upjohn Co., Kalamazoo, MI 49001 \\ Accepted for publication August 10, 1984
}

Cell growth and lincomycin production were measured in batch cultures of Streptomyces lincolnensis in chemically defined media. In these fermentations the specific rate of antibiotic production was maximal during growth and always declined at the end of the growth phase. It was found that both phosphate and ammonium salts, while required for cell growth, had negative effects on antibiotic production. By increasing the concentration of magnesium sulfate, it was possible to increase both the production rates and final titers of lincomycin. The mechanism for this effect was found to be the reduction of soluble phosphate in the medium through the precipitation of ammonium magnesium phosphate. Lincomycin production rates were not inhibited by glucose at concentrations of up to $30 \mathrm{~g} / \mathrm{L}$.

\section{INTRODUCTION}

The objective of this study was to investigate growth and lincomycin production in an industrial strain of $S$. lincolnensis in chemically defined media. Interactions between an antibiotic-producing culture and its chemical environment have long been known to play an important role in determining the rates of production and yields of the antibiotic. The repression of enzymes required for actinomycin synthesis by glucose is a classic example ${ }^{1}$. Many other examples of nutrient effects on antibiotic synthesis exist and have been the subjects of some excellent reviews ${ }^{2,3}$. Here we report the results of our studies of how the chemical environment affects the processes of cell growth and antibiotic production in the lincomycin fermentation.

These studies were done in a chemically defined medium so that substrate uptake and cell growth could

\footnotetext{
* Current Address: Fermentation R\&D, The Upjohn Co., Kalamazoo, MI 49001.

† Current Address: Industrial Div., Bristol-Myers Co., Syracuse, NY 13221.
}

Biotechnology and Bioengineering, Vol. XXVII, Pp. 327-333 (1985)

(c) 1985 John Wiley \& Sons, Inc. be measured directly and complicating medium interactions minimized. Using this experimental system, it was our goal to isolate and identify the effects of glucose, phosphate, and ammonium on cell growth and antibiotic production for the lincomycin fermentation.

\section{MATERIALS AND METHODS}

\section{General}

All chemicals were reagent grade. All solutions were made with water purified by reverse osmosis and having a dissolved solids concentration of less than $10 \mathrm{mg} / \mathrm{L}$.

\section{Culture}

The culture used for this study was a mutant strain of $S$. lincolnensis that was derived from the parent strain NRRL 2936. Lyophilized spore preparations of the strain were used to prepare stock cultures on agar slants. These cultures were well sporulated and were stored at $4^{\circ} \mathrm{C}$ for up to 4 months before use.

\section{Shake Flask Procedures}

Shake flasks were used for the preliminary work to determine the effects of the minor minerals on the fermentation. Seed for the shake flasks was prepared in a clear, complex medium, containing $10 \mathrm{~g} / \mathrm{L}$ glucose, $10 \mathrm{~g} / \mathrm{L}$ Difco yeast extract, and $5 \mathrm{~g} / \mathrm{L} \mathrm{N}-\mathrm{Z}$ Amine B (Humko Sheffield). A flask containing $100 \mathrm{~mL}$ of medium was inoculated with one loopful of spores from a stock culture. Incubation was carried out in $500-\mathrm{mL}$ wide-mouth Erlenmeyer flasks at $28^{\circ} \mathrm{C}$ on a rotary shaker using a 2 -in. orbit and operating at $250 \mathrm{rpm}$. The flasks were incubated for $48 \mathrm{~h}$; the mycelia were 
harvested by centrifugation and aseptically washed three times with purified water.

The media used in the shake flask studies were adaptations of that reported by Witz et al. ${ }^{4}$ They contained glucose $30 \mathrm{~g} / \mathrm{L}$, sodium citrate dihydrate 3.4 $\mathrm{g} / \mathrm{L}, \mathrm{K}_{2} \mathrm{HPO}_{4} 2.5 \mathrm{~g} / \mathrm{L}$, and $\mathrm{NH}_{4} \mathrm{NO}_{3} 2.0 \mathrm{~g} / \mathrm{L}$, along with various amounts of $\mathrm{FeSO}_{4}, \mathrm{MgSO}_{4}, \mathrm{ZnSO}_{4}$, and $\mathrm{NaCl}$. Glucose, the sulfate salts, and sodium chloride were dissolved, brought to $90 \%$ of the final solution volume, placed in the flasks, and autoclaved. The remaining ingredients were made up as a 10 -fold concentrate, adjusted to $\mathrm{pH} 7.0$ with sulfuric acid, filter sterilized, and added separately.

\section{Fermentation Procedure}

All studies were carried out in 14-L (10-L working volume) laboratory fermentors of standard design (Microferm ${ }^{\circledR}$, New Brunswick Scientific). The $\mathrm{pH}$ of the fermentations tended to fall and was controlled at $\mathrm{pH}$ 7.0 by the automatic addition of $5 \mathrm{~N} \mathrm{NaOH}$ solution. Aeration $(0.33 \mathrm{vvm})$ and agitation $(400 \mathrm{rpm})$ were sufficient to maintain the dissolved oxygen concentration at values above $80 \%$ of saturation. The tendency of the fermentation to foam was controlled by regular additions of small amounts of a silicone antifoam agent.

One loopful of spores from a stock slant was used to inoculate $5 \mathrm{~L}$ seed medium in a $7 \mathrm{~L}$ fermentor. The same seed medium was used as for the shake flask studies. The seed cultures were harvested after about $48 \mathrm{~h}$ of incubation at $28^{\circ} \mathrm{C}$. The harvested cells were aseptically washed three times with a $6 \mathrm{mM}$ phosphate buffer. A sufficient quantity of washed cells was added to the fermentor to bring the biomass concentration to $0.08 \mathrm{~g} / \mathrm{L}$.

The media used for studies in the fermentors contained only glucose and mineral salts, as described later. The glucose and minor salts were dissolved in the fermentor and autoclaved. The phosphate and ammonium salts were sterilized by filtration and added separately.

\section{Analytical}

Biomass concentrations were measured by collecting cells from a known volume of sample on a membrane filter (HATF, $47 \mathrm{~mm}$, Millipore), washing with three 10-mL aliquots of water and drying to constant weight at $55^{\circ} \mathrm{C}$. Lincomycin concentration was measured by an automated assay following the method of Prescott. ${ }^{5}$ Glucose was measured in an automated assay using the Trucose reagent (Fisher Scientific) that is an adaptation of the assay reported by Hultman. ${ }^{6}$ Phosphate was measured by the molybdovanadate assay of Fogg and Wilkinson. ${ }^{7}$ Ammonia nitrogen was measured in a Kjeldahl apparatus, omitting the digestion step. All assays for medium components were performed on samples that were first filtered through Whatman 2 filter paper to remove mycelia.

\section{Estimation of the Specific Rate of Lincomycin Production}

Data for lincomycin and biomass concentrations were plotted and graphically interpolated at 5-h intervals. The interpolated lincomycin values were numerically differentiated using the second-order central-difference formula. The specific rate was then estimated at 5 -h intervals by dividing the rate of production of lincomycin by the biomass concentration. Results are expressed as milligrams of lincomycin produced per gram of biomass per hour.

\section{RESULTS}

\section{Minor Mineral Studies}

Shake flask studies were conducted using variations of the medium described by Witz et al. ${ }^{4}$ The concentration of each of the minor mineral salts was varied in a series of flask cultures to determine whether any of the minerals limited either cell growth or production of lincomycin. The results are shown in Table I. From these studies levels of $\mathrm{FeSO}_{4} \cdot 7 \mathrm{H}_{2} \mathrm{O}$ and $\mathrm{ZnSO}_{4} \cdot 7 \mathrm{H}_{2} \mathrm{O}$ were set at 2.0 and $1.0 \mathrm{mg} / \mathrm{L}$, respectively, and $\mathrm{NaCl}$ was eliminated from the medium. Experiments with magnesium and potassium sulfates suggested that magnesium had a stimulatory effect on antibiotic production that was independent of cell growth. Further investigation of this effect was left for studies in the fermentors.

The medium was further simplified to study the effects of individual substrates on the fermentation in laboratory fermentors. Trisodium citrate was eliminated and the ammonium nitrate was replaced with ammonium chloride with the realization that $\mathrm{pH}$ control would be required since the uptake of ammonium by the culture would result in a decrease in $\mathrm{pH}$.

\section{The Standard Run}

Figure 1 shows the substrate and product profiles for a batch fermentation carried out in a laboratory fermentor on the redesigned defined medium. The biomass curve exhibited the classical phases of growth, stasis, and decline. The growth portion of the curve was well fitted by an exponential function yielding a growth rate constant of 0.035 inverse hours. Lincomycin was produced during all three phases of the fermentation, although at varying rates in each. The maximum biomass and lincomycin concentrations attained were $9.5 \mathrm{~g} / \mathrm{L}$ and $360 \mathrm{mg} / \mathrm{L}$, respectively. This run was nitrogen limited in the sense that ammonia nitrogen was the first substrate to fall below detectable limits. This occurred at about $100 \mathrm{~h}$. Glucose depletion occurred at about $120 \mathrm{~h}$, and phosphate uptake ceased before it was depleted.

The specific rate of lincomycin production is plotted as a function of biomass concentration in Figure 2. It 
Table I. Effects of minor minerals on cell growth and lincomycin production in shake flasks. ${ }^{a}$

\begin{tabular}{|c|c|c|c|c|c|}
\hline & & & & & * \\
\hline \multirow{4}{*}{$\begin{array}{l}\text { Magnesium } \\
\text { experiment }\end{array}$} & $\mathrm{MgSO}_{4} \cdot 7 \mathrm{H}_{2} \mathrm{O}(\mathrm{g} / \mathrm{L})$ & 0.00 & 0.10 & 0.50 & 1.00 \\
\hline & $\mathrm{K}_{2} \mathrm{SO}_{4}{ }^{\mathrm{b}}(\mathrm{g} / \mathrm{L})$ & 0.71 & 0.64 & 0.34 & 0.00 \\
\hline & Lincomycin (mg/L) & $<25$ & 49 & 95 & 135 \\
\hline & Biomass $(\mathrm{g} / \mathrm{L})$ & $\begin{array}{c}0.0 \\
*\end{array}$ & 5.7 & 4.8 & 4.2 \\
\hline \multirow{3}{*}{$\begin{array}{l}\text { Sulfate } \\
\quad \text { experiment }\end{array}$} & $\mathrm{K}_{2} \mathrm{SO}_{4}(\mathrm{~g} / \mathrm{L})$ & 0.0 & 0.71 & 3.50 & \\
\hline & Lincomycin $(\mathrm{mg} / \mathrm{L})$ & 135 & 127 & 124 & \\
\hline & Biomass $(\mathrm{g} / \mathrm{L})$ & 4.2 & 4.8 & $\begin{array}{l}4.7 \\
*\end{array}$ & \\
\hline \multirow{3}{*}{$\begin{array}{l}\text { Zinc } \\
\quad \text { experiment }\end{array}$} & $\mathrm{ZnSO}_{4} \cdot 7 \mathrm{H}_{2} \mathrm{O}(\mathrm{mg} / \mathrm{L})$ & 0.0 & 0.5 & 1.0 & 5.0 \\
\hline & Lincomycin $(\mathrm{mg} / \mathrm{L})$ & 100 & 101 & 135 & 122 \\
\hline & Biomass $(\mathrm{g} / \mathrm{L})$ & 5.5 & 4.9 & $\begin{array}{l}4.2 \\
*\end{array}$ & 4.8 \\
\hline \multirow{3}{*}{$\begin{array}{l}\text { Iron } \\
\quad \text { experiment }\end{array}$} & $\mathrm{FeSO}_{4} \cdot 7 \mathrm{H}_{2} \mathrm{O}(\mathrm{mg} / \mathrm{L})$ & 0.0 & 0.5 & 1.0 & 10.0 \\
\hline & Lincomycin $(\mathrm{mg} / \mathrm{L})$ & 24 & 117 & 135 & 130 \\
\hline & Biomass $(\mathrm{g} / \mathrm{L})$ & 3.2 & $\begin{array}{l}5.8 \\
*\end{array}$ & 4.8 & 4.7 \\
\hline \multirow{3}{*}{$\begin{array}{l}\text { Sodium chloride } \\
\text { experiment }\end{array}$} & $\mathrm{NaCl}(\mathrm{g} / \mathrm{L})$ & 0.0 & 0.5 & 1.0 & 2.5 \\
\hline & Lincomycin (mg/L) & 133 & 135 & 137 & 125 \\
\hline & Biomass $(\mathrm{g} / \mathrm{L})$ & 5.2 & 4.2 & 4.7 & 5.1 \\
\hline
\end{tabular}

${ }^{a}$ Asterisk indicates basal medium, consisting of: glucose $30 \mathrm{~g} / \mathrm{L}, \mathrm{Na}_{3}$ Citrate $2 \mathrm{H}_{2} \mathrm{O} 3.4 \mathrm{~g} / \mathrm{L}, \mathrm{NH}_{4} \mathrm{NO}_{3} 2.0 \mathrm{~g} / \mathrm{L}, \mathrm{K}_{2} \mathrm{HPO}_{4} 2.5 \mathrm{~g} / \mathrm{L}, \mathrm{MgSO}_{4} \cdot 7 \mathrm{H}_{2} \mathrm{O} 1 \mathrm{~g} / \mathrm{L}, \mathrm{ZnSO}_{4}$. $7 \mathrm{H}_{2} \mathrm{O} 1 \mathrm{mg} / \mathrm{L}, \mathrm{FeSO}_{4} \cdot 7 \mathrm{H}_{2} \mathrm{O} 1 \mathrm{mg} / \mathrm{L}$, and $\mathrm{NaCl} 0.5 \mathrm{~g} / \mathrm{L}$. Deviations from basal medium are indicated in each experimental set. Values reported for lincomycin and biomass concentrations are the averages of duplicate flasks.

${ }^{\mathrm{b}} \mathrm{K}_{2} \mathrm{SO}_{4}$ added to maintain starting sulfate concentration at $4 \mathrm{mM}$.
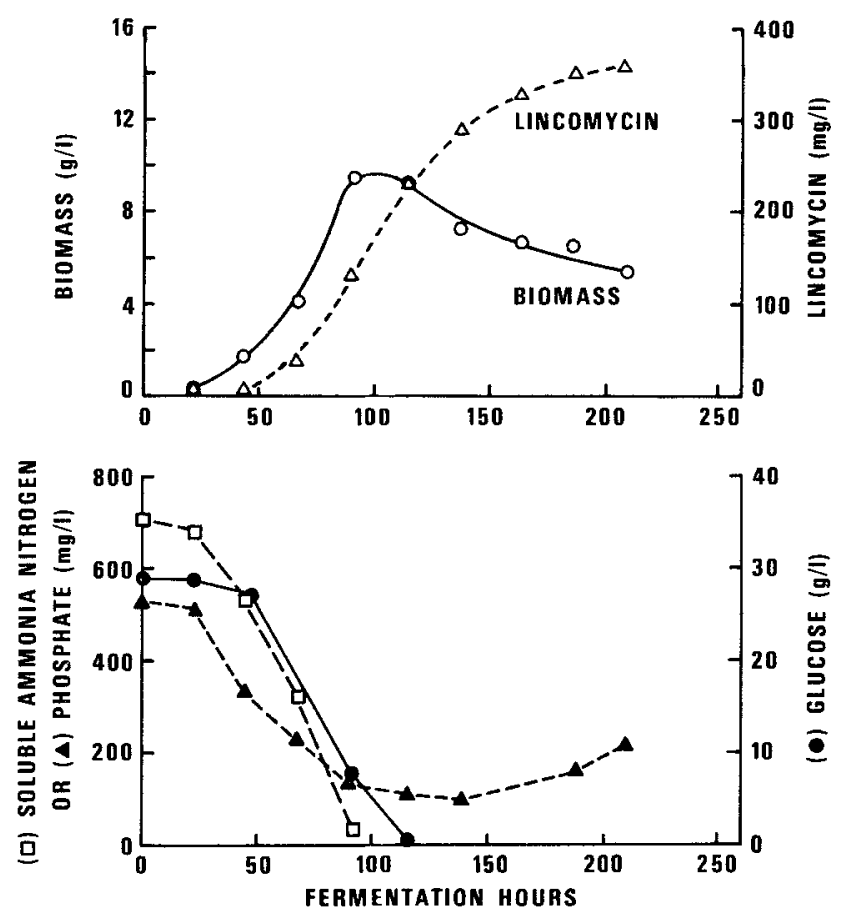

Figure 1. Substrate, biomass, and product profiles for the standard batch fermentation in chemically defined medium. Medium contained glucose $30 \mathrm{~g} / \mathrm{L}, \mathrm{K}_{2} \mathrm{HPO}_{4} \mathrm{I} \mathrm{g} / \mathrm{L}, \mathrm{MgSO}_{4} \cdot 7 \mathrm{H}_{2} \mathrm{O} 1 \mathrm{~g} / \mathrm{L}, \mathrm{NH}_{4} \mathrm{Cl} 2.7$ $\mathrm{g} / \mathrm{L}, \mathrm{FeSO}_{4} \cdot 7 \mathrm{H}_{2} \mathrm{O} 2 \mathrm{mg} / \mathrm{L}$, and $\mathrm{ZnSO}_{4} 7 \mathrm{H}_{2} \mathrm{O} 1 \mathrm{mg} / \mathrm{L}$.

showed a modest increase during the growth phase, rising from 0.45 to $0.67 \mathrm{mg} / \mathrm{g} \mathrm{h}$. As the stationary phase was approached, the rate dropped rapidly and continued to decline during the phase of declining biomass concentration.

\section{Effects of Phosphate}

We found that phosphate regulated lincomycin production. This effect extended over most of the range of phosphate concentrations investigated. Some examples are shown in Figure 3. The three fermentations

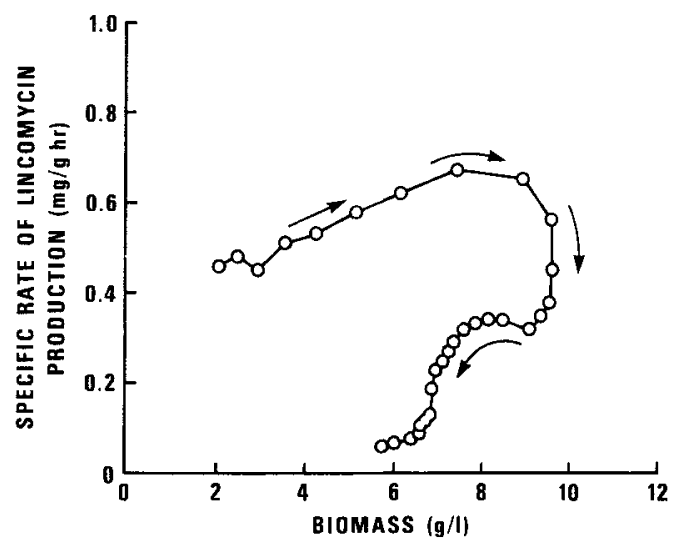

Figure 2. Specific rate of lincomycin production plotted as a function of biomass concentration for the standard fermentation shown in Figure 1. Points represent $5-\mathrm{h}$ intervals and the arrows indicate the direction of increasing time. 

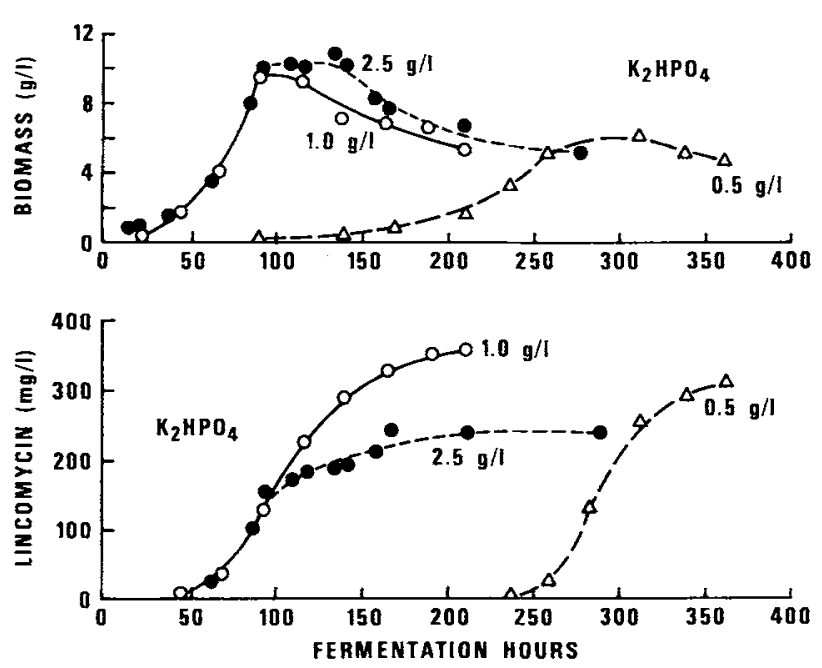

Figure 3. Biomass and lincomycin profiles for fermentations with varying concentrations of $\mathrm{K}_{2} \mathrm{HPO}_{4}$. All other medium components were added at the same concentration as in the standard fermentation.

shown in this figure were run in similar media except that the starting concentration of $\mathrm{K}_{2} \mathrm{HPO}_{4}$ was varied from 0.5 to $2.5 \mathrm{~g} / \mathrm{L}$. The runs with 1 and $2.5 \mathrm{~g} / \mathrm{L}$ $\mathrm{K}_{2} \mathrm{HPO}_{4}$ showed similar growth profiles, while the run with $0.5 \mathrm{~g} / \mathrm{L}$ exhibited a considerable lag phase and did not attain as high a biomass concentration. Increasing $\mathrm{K}_{2} \mathrm{HPO}_{4}$ from 1 to $2.5 \mathrm{~g} / \mathrm{L}$ resulted in a decline in lincomycin production by $33 \%$. The run with 0.5 $\mathrm{g} / \mathrm{L} \mathrm{K}_{2} \mathrm{HPO}_{4}$ produced almost as much lincomycin as the run with $1 \mathrm{~g} / \mathrm{L}$, even though the production of lincomycin was delayed and the biomass concentration was reduced.

The specific rate of lincomycin production is plotted as a function of biomass concentration for these runs in Figure 4. These plots include data for the growth

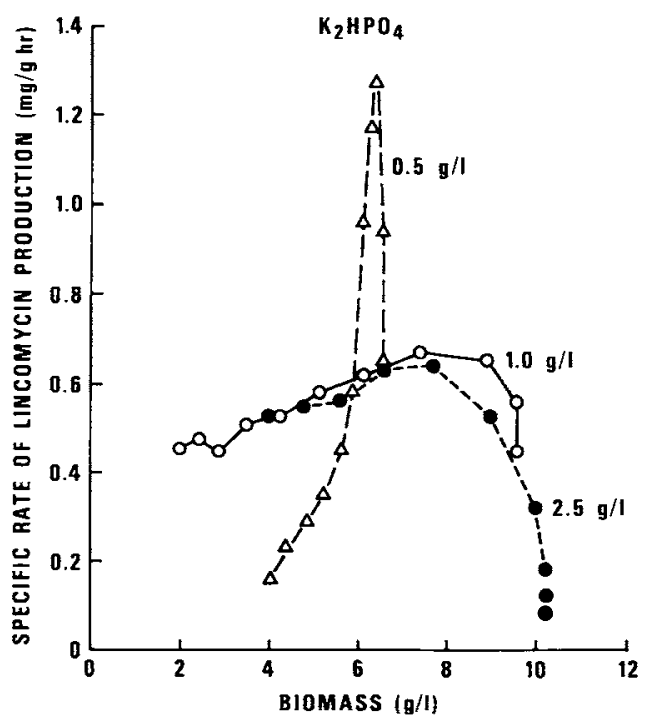

Figure 4. Specific rate of lincomycin production plotted as a function of biomass concentration for the fermentations shown in Figure 3. portion of the biomass curve only. A reduction of from 1 to $0.5 \mathrm{~g} / \mathrm{L} \mathrm{K} \mathrm{K}_{2} \mathrm{HPO}_{4}$ resulted in an increase in the specific rate of antibiotic production. The peak specific rate for the low phosphate run occurred at lower values of biomass concentration because the biomass did not reach as high a level in this fermentation as it did in the higher phosphate runs. Thus, while phosphate is required for growth, it also depresses lincomycin production rates.

\section{Effects of Magnesium Sulfate}

Because of results reported in Table I on the effect of magnesium sulfate on antibiotic production, fermentations were conducted in which the starting $\mathrm{MgSO}_{4} \cdot 7 \mathrm{H}_{2} \mathrm{O}$ concentrations were 1,2 , and $5 \mathrm{~g} / \mathrm{L}$. The data are shown in Figure 5. Increased concentrations of magnesium sulfate caused delays in growth, although the same peak biomass concentrations were eventually attained in all three cases. Lincomycin production reached higher levels with higher magnesium sulfate concentrations. The specific rate of lincomycin synthesis was also increased with increasing magnesium sulfate concentrations, as shown in Figure 6.

A small amount of crystalline material was observed microscopically in the media prepared with higher magnesium sulfate concentrations. It was possible to increase the formation of this material by the progressive addition of magnesium sulfate and potassium phosphate
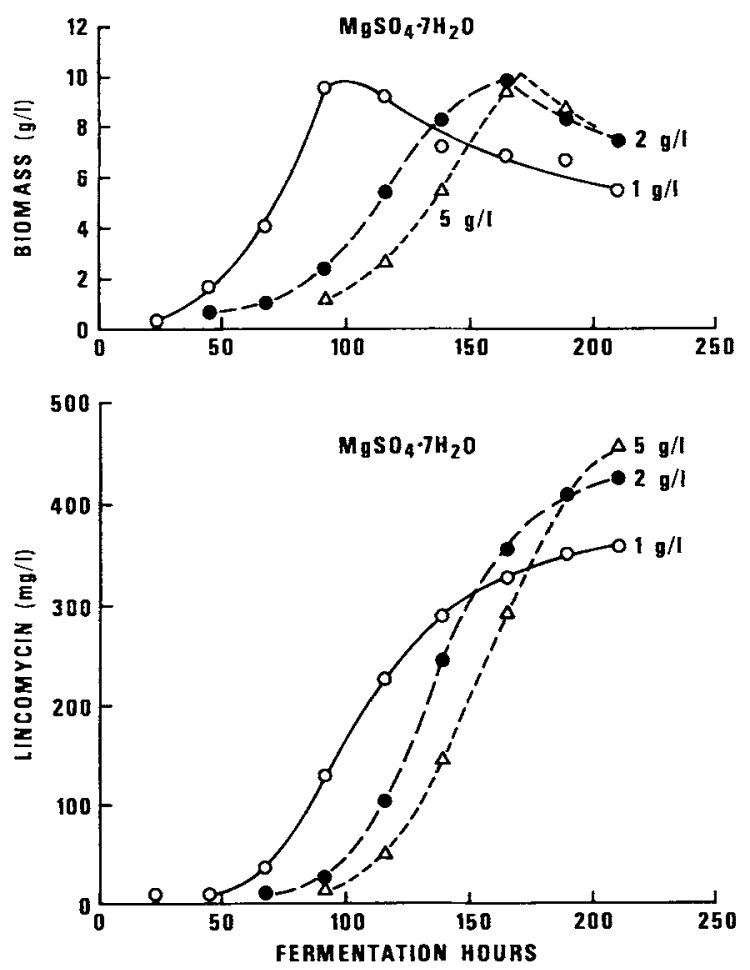

Figure 5. Biomass and lincomycin profiles for fermentations with varying concentrations of magnesium sulfate. All other medium components were added at the same concentration as in the standard fermentation. 


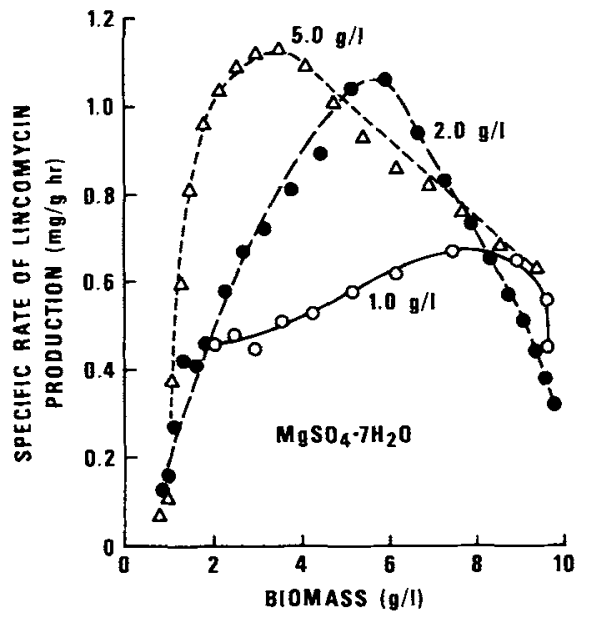

Figure 6. Specific rate of lincomycin production plotted as a function of biomass concentration for the fermentations shown in Figure 5.

to the defined medium. Crystals were collected, washed with acetone, and analyzed by X-ray crystallography. They were identified as $\mathrm{MgNH}_{4} \mathrm{PO}_{4} \cdot 6 \mathrm{H}_{2} \mathrm{O}$. Examination of solubility data for this compound shows an extremely low solubility product constant at about $10^{-13.8}$ The $\mathrm{pH}$ also affects the solubility by shifting the biphosphatephosphate equilibrium, but at $\mathrm{pH} 7.0$ and with the levels of ammonia nitrogen employed, the phosphate concentration becomes very small as its molar concentration falls below that of magnesium.

The same biomass concentration was attained in all three runs shown in Figure 5, suggesting that either the yield coefficient for phosphate changed or that the ammonium magnesium phosphate was solubilized. One run was made with $2.5 \mathrm{~g} / \mathrm{L}$ of $\mathrm{K}_{2} \mathrm{HPO}_{4}$ and $5 \mathrm{~g} / \mathrm{L}$ $\mathrm{MgSO}_{4} \cdot 7 \mathrm{H}_{2} \mathrm{O}$, so that the magnesium concentration was in molar excess over phosphate. Soluble phosphate was measured, and its profile is shown in Figure 7. Note that the soluble phosphate concentration increased throughout the growth phase, favoring the solubilization theory.

The reduction in soluble phosphate caused by its precipitation has two effects. First, a low concentration of phosphate results in a lag in cell growth, presumably caused by nutrient limitation. The second effect is to increase the specific rate of lincomycin production. This can be seen clearly in Figure 6.

\section{Ammonia Nitrogen Effects}

The effects of ammonia nitrogen on the fermentation were qualitatively similar to those of phosphate. This is shown in Figure 8, where the specific rate of lincomycin production is plotted against biomass concentration (growth phase only). The four curves in this figure were obtained from four fermentations with different starting ammonium chloride concentrations. At $2800 \mathrm{mg} / \mathrm{L}$ of starting ammonia nitrogen $(10.8 \mathrm{~g} / \mathrm{L}$ of $\mathrm{NH}_{4} \mathrm{Cl}$ ) cell growth followed the normal pattern
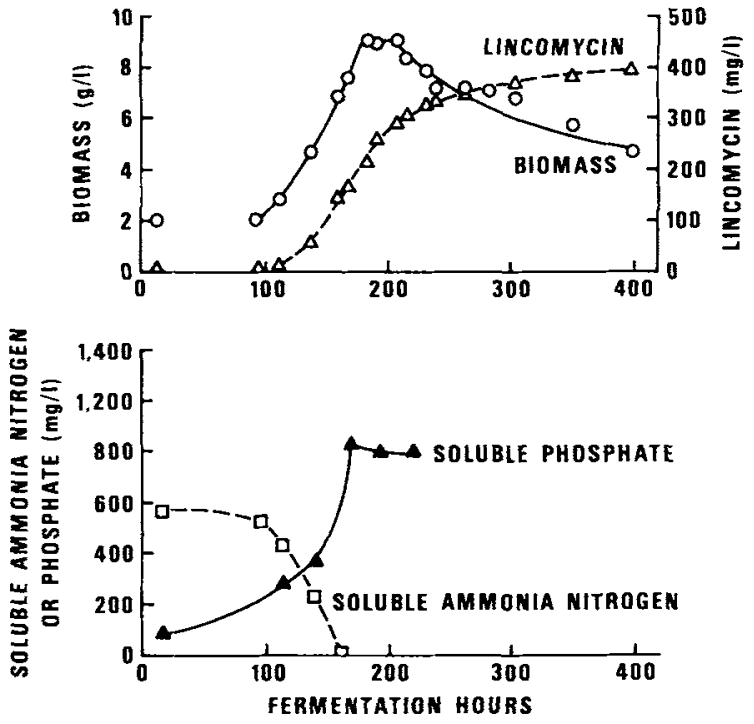

Figure 7. Biomass, lincomycin, and substrate profiles for a fermentation with $2.5 \mathrm{~g} / \mathrm{L} \mathrm{K}_{2} \mathrm{HPO}_{4}$ and $5.0 \mathrm{~g} / \mathrm{L} \mathrm{MgSO}_{4} \cdot 7 \mathrm{H}_{2} \mathrm{O}$. All other medium components were added at the same concentration as in the standard fermentation.

(not shown), but no lincomycin was produced. Lower starting nitrogen concentrations resulted in higher specific rates of lincomycin production over the range tested. The possible effect of chloride on the fermentation was ruled out because of the original studies with sodium chloride (see Table I). The earlier peaks in specific rate for lower $\mathrm{NH}_{4} \mathrm{Cl}$ concentrations resulted from progressively stricter nitrogen limitation of cell growth.

\section{Glucose Effects}

The sole source for both carbon and energy for cell growth and maintenance in these fermentations was glucose. Also, it was the only exogenous source of carbon and energy for antibiotic synthesis, although during some parts of the fermentation cycle there may have been other, endogenous energy and carbon sources to fulfill this role. Glucose has commonly been observed to repress the synthesis of enzymes that are required for antibiotic production. That does not appear to happen in this case. The peak specific rate of lincomycin production occurred early in many of these fermentations, when high concentrations of glucose remained. An example of this is shown in Figure 8. The run containing $350 \mathrm{mg} / \mathrm{L}$ of ammonia nitrogen reached a specific rate in excess of $1 \mathrm{mg} / \mathrm{g} \mathrm{h}$ at a point when the glucose concentration was over $20 \mathrm{~g} / \mathrm{L}$.

In one experiment a fermentation received two additions of glucose. One of the additions was made during active growth, when positive concentrations of all three of the major nutrients were present, and one after growth had ceased because of nitrogen depletion. Both additions resulted in an increase in glucose concentration of $19 \mathrm{~g} / \mathrm{L}$, bringing the concentration of 


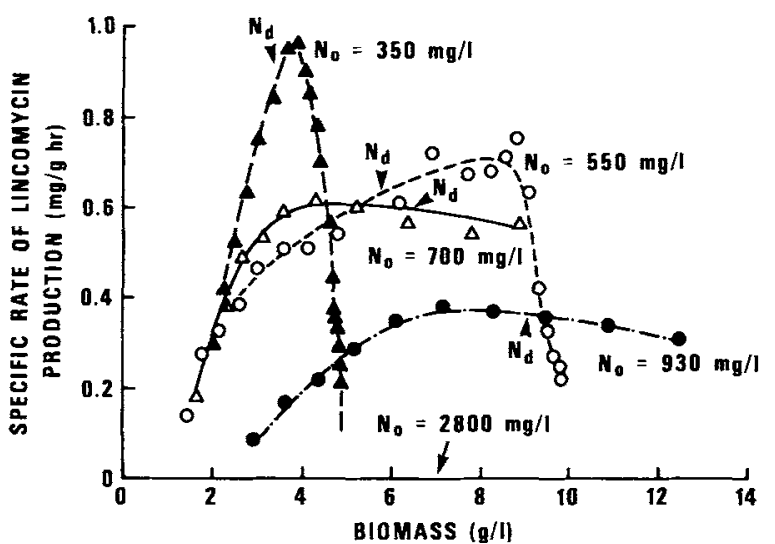

Figure 8. Specific rate of lincomycin production plotted as a function of biomass concentration for fermentations with varying concentrations of $\mathrm{NH}_{4} \mathrm{Cl}$. All other medium components were the same as in the standard fermentation. Arrows labeled $N_{d}$ on these plots show the point at which ammonia was depleted from the medium.

glucose in the fermentor to $30 \mathrm{~g} / \mathrm{L}$. This experiment also included a control that received no additions. These two fermentations are shown in Figure 9.

The glucose additions did not appear to inhibit lincomycin production; in fact lincomycin accumulation was increased by about $20 \%$ in the run receiving the
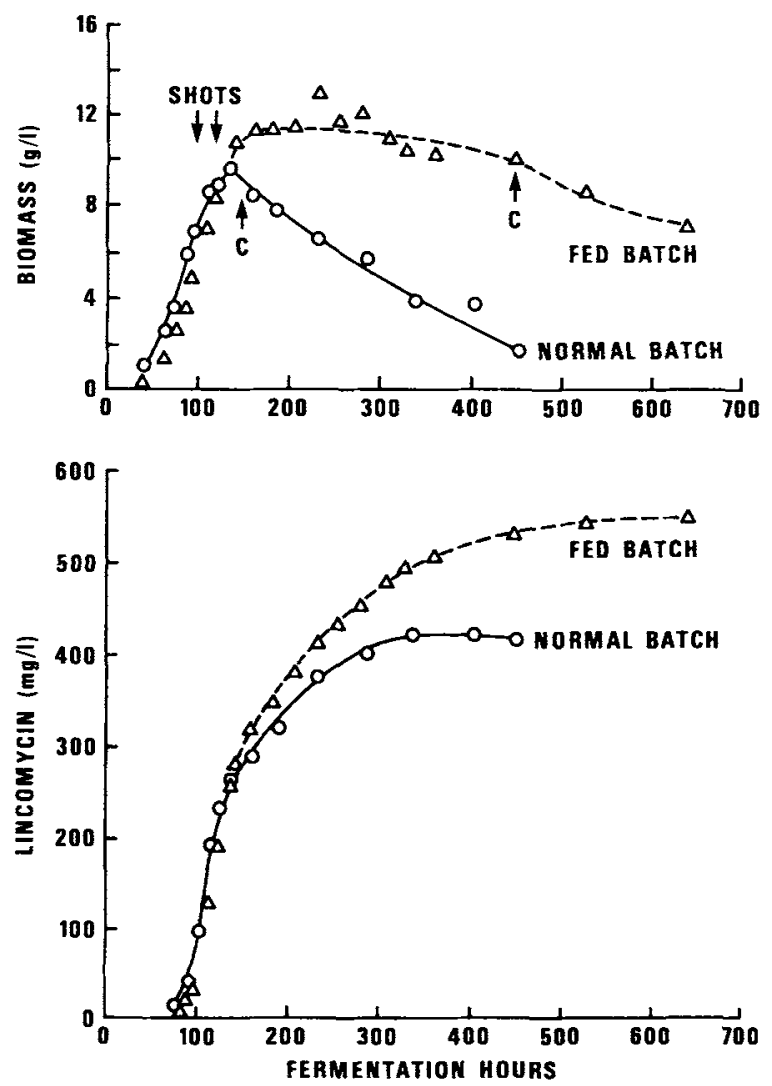

Figure 9. Biomass and lincomycin profiles for normal batch and glucose fed batch fermentations. Starting medium composition was that of the standard fermentation. The fed batch received two glucose additions of $19 \mathrm{~g} / \mathrm{L}$ (indicated by arrows labeled shots). Arrows labeled $C$ indicate points where glucose depletion occurred. additions. The specific rates of lincomycin production are plotted as functions of biomass concentration in Figure 10. Based on these results, glucose can be ruled out as an effector of lincomycin biosynthesis in this medium.

\section{CONCLUSIONS}

These studies have shown that in chemically defined media lincomycin production occurs at its maximum specific rate during the phase of cell growth. Once growth is halted by depletion of one or more nutrients, the specific rate of lincomycin production falls rapidly. This result is at variance with the idea implicit in the assignment of such terms as trophophase and idiophase to the sequence of events occurring during the course of an antibiotic fermentation. ${ }^{9}$ This finding supports a more modern view as described in a review by Aharonowitz and Demain, ${ }^{10}$ wherein the nutritional environment determines whether secondary metabolism occurs during or after cell growth.

Furthermore, antibiotic production rates are strongly affected by two of the three major media components tested. This regulatory function of the substrates has significant implications in the interpretation of classical results such as those of Bu'Lock ${ }^{9,11}$ and Weinberg ${ }^{12}$ : here antibiotic production was assumed to occur only after growth had nearly ceased or had stopped completely. If nutrients regulate antibiotic production, then cell growth per se may not be the controlling factor for secondary metabolism.

Growth ceases on depletion of a vital nutrient, and it is possible that the depletion of nutrients is the mechanism by which secondary metabolism is allowed to occur. Therefore, it may be possible to develop strategies to regulate the supply of nutrients to allow both cell growth and optimal antibiotic production. This was demonstrated in our studies by the precipitation of ammonium magnesium phosphate. The pre-

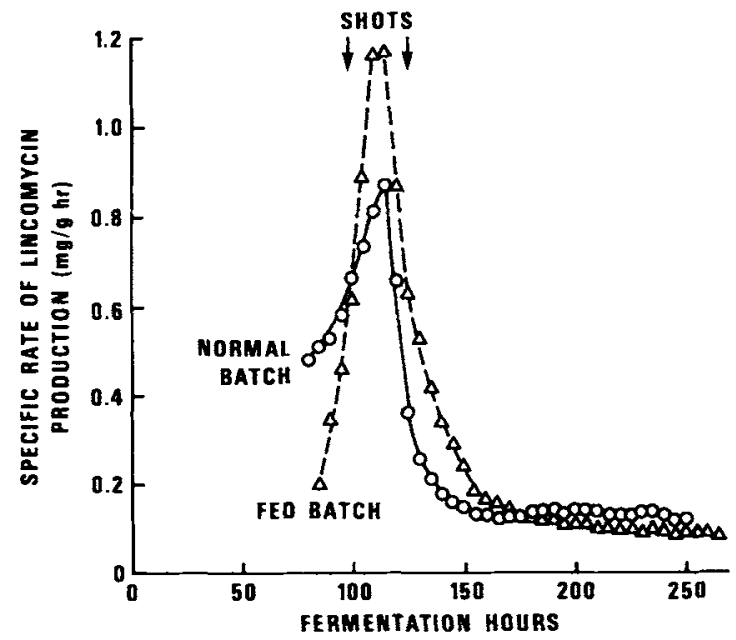

Figure 10. Specific rate of lincomycin production plotted as a function of fermentation time for the run shown in Figure 9. 
cipitate served as a source of phosphate but limited the free phosphate concentration during part of the fermentation, thus stimulating lincomycin production.

The coprecipitation of magnesium and ammonia as phosphate and its effects on antibiotic production has been reported recently for other fermentations. ${ }^{13}$ In those studies the effect appears to have been related to a reduction in the free ammonia concentration. This mechanism may have a general application in relieving nutrient regulation of antibiotic synthesis.

The authors wish to thank The Upjohn Company for financial and analytic support of this project.

\section{References}

1. M. Gallo and E. Katz, J. Bact., 109, 659 (1972).
2. S. W. Drew and A. L. Demain, Ann. Rev. Microbiol., 31, 343 (1977).

3. J. F. Martin and A. L. Demain, Microbiol. Rev. 44, 230 (1980).

4. D. F. Witz, E. J. Hessler, and T. L. Miller, Biochemistry, 10, 1128 (1971).

5. G. C. Prescott, J. Pharm. Sci., 55, 423 (1966).

6. E. Hultman, Nature, 183, 108 (1959).

7. D. N. Fogg and N. T. Wilkinson, Analyst, 83, 406 (1958).

8. J. J. Lingane, Analytical Chemistry of Selected Organic Compounds (Reinhold Publishing Co., New York, 1966).

9. J. D. Bu'Lock, D. Hamilton, M. A. Hulme, A. J. Smalley, D. Shepherd, and G. N. Smith, Can. J. Microbiol., 11, 765 (1965).

10. Y. Aharonowitz and A. L. Demain, Biotechnol. Bioeng., Suppl. 1, 22, 5 (1980).

11. J. D. Bu'Lock, R. D. Detroy, E. Hostalek, and A. Munim-AlShakarchi, Trans. Br. Mycol. Soc., 62, 377 (1974).

12. E. D. Weinberg, Adv. Microb. Physiol., 4, 1 (1970).

13. Y. Tanaka, Y. Takahashi, R. Masuma, Y. Iwai, H. Tanaka, and S. Omura, Agric. Biol. Chem., 45, 2475 (1981). 